\title{
Marketing of Information Products \& Services by the Research Scholars \& Scientists in Central Soil Salinity Research Institute, Karnal: A study
}

\author{
${ }^{1}$ Anil Kumar (Gold Medalist), ${ }^{2}$ Dr. Joginder Singh, ${ }^{3}$ Diksha \\ ${ }^{I}$ (Librarian, Swift Group of Colleges, Rajpura, Patiala (Punjab), India) \\ ${ }^{2}$ (Associate Prof, Department of Library \& Information Science, Kurukshetra University Kurukshetra, \\ Haryana, India) \\ ${ }^{3}$ (HR, Swift Group of Colleges, Rajpura, Patiala (Punjab), India)
}

\begin{abstract}
The present study has been undertaken to assess the Marketing of Information Products \& Services by Central Soil Salinity Research Institute under the Indian Council of Agricultural Research in all the disciplines of CSSRI, Karnal. A well structured questionnaire was distributed among the research-scholars and Scientists of four departments viz Soil and Crop Management, Irrigation and Drainage Engineering, Crop Improvement \& also Technology Evaluation and Transfer under the Central Soil Salinity Research Institute karnal. The responses were gathered from 35 users (30 Scientists and 05 Research Scholars).The findings of the survey reveal useful facts about the Marketing of Information Products \& Services gender wise use the CSSRI library male respondents were $82.85 \%$ than female respondents which were $17.14 \%$. Only14.28\% respondents were used the off line library that thrice in a Week, $5.71 \%$ daily and $28.57 \%$ occasionally. In fact $34.28 \%$ users were using the online library daily, $11.42 \%$ weekly and $5.71 \%$ Scientists thrice in a week use the online library. CSSRI Respondents were 100\% using the library for the purpose of Research work \& Writing/Presenting paper, and update knowledge which were the second purpose for which users use the library i.e. $71.42 \%$. The third purpose for using the library i.e. $34.28 \%$ users were teaching and $22.85 \%$ education regarding which used the library by Scientists on CSSRI, Karnal. Only14.28\% respondents were positively using the library for entertainment only. On the basis of the findings, it was suggested that the intensive effort was required from the part of the top management of the library, and authorities of the concerned ICAR to overcome the identified weakness. Most of the respondents gave proper feedback mechanism to monitor the effectiveness of the services and products. Regular surveys of the respondents should be conducted to know the continuity/discontinuity of the existing services/products and initiation of new services/products. It was also suggested that it should adopt some of the marketing and promotional strategies including publications, programmers of events, media and effective presentation of information products and services through the library website.
\end{abstract}

Keywords: Information Products and Services, CSSRI, Library services, Marketing, Products, use.

\section{Introduction}

In the knowledge based society \& economy of the $21^{\text {st }}$ century, users' expectations and engagement with knowledge \& information have grown in sophistication. Recent decades have witnessed an explosion in the quantity of information being produced, which in turn has created vast opportunities for information-based businesses. The time has come for information to be treated as a unique product with goods \& services.

In the present age of information technology, libraries \& information centers have become profit making organizations due to adoption of new technological storage, processing, retrieval \& services. Instead of the user approaching for information services in the libraries or information centers, the information must reach the user's place of work; whether it is a classroom, or the research laboratory, the home or any other place of activity in any field of life (Kotler and Andreasen, 1995). Before 1970, the concept of marketing was confined almost exclusively to organizations supplying products rather than services. Although the idea of applying marketing principles to library activity was realized by S. R. Ranganathan in 1930s himself and on the basis of which the five laws of library science were formulated by him (Mandal, Poddar and Choudhury, 1998).

Over the last few years, a number of information services have been experimenting with modern marketing methods or at least in certain aspects of marketing such as advertising and public relations. The marketing approach may profoundly modify the perspective of information products and services just as it transformed the business world some years ago. The application of information technology (IT) based marketing approach in information products and services would be quite radical and dynamic as it forces the organization to the competitive business world. Now-a-days, marketing acts as a driving force in achieving quality library 
and information products and services and maximizing users' satisfactions at the minimum producing and delivery cost. This fact is more important in case of special libraries. This study is an attempt to assess how the special libraries in Bangladesh do apply the marketing orientation to create superior values to users.

The Research Libraries in India have been reflected as social and non-profit service oriented organizations providing information to their members from a long time past. Over a period of time, due to change in the nature of demands by the users, libraries have extended their functions to include documentation and document delivery systems (Munshi, 2004). The libraries have also been initiated to make them as profit making organizations providing better information products and services to users.

\section{Concept of Marketing}

Basic to all of the marketing is the idea of "responsive organization" just described. Given an organization that is open to personal suggestions from its clients and that is flexible and creative enough to adapt itself or its services to meet the changing needs and demands of these clients, certain questions face the organization. Five key marketing concepts relate to these questions (Zachert, 1986).

Marketing activities are a prominent part of life today. Many people work in marketing jobs or holding positions with marketing departments. Most people think of marketing solely as advertising or selling. In reality, marketing is much more than selling the product or services. It is one to one interaction and an exchange of value in which both parties 'gain something'. Information professionals may not realize that they themselves are already engaged in some marketing activities every day. Information professionals have to recognize that creating and following a marketing plan is an invaluable tool; they should learn how to harness its power to benefit the corporate library and the enterprise as a whole (Brown, 1997).

The difference between selling and marketing is that 'selling focuses on the needs of the buyer'. Levitt goes on to say that marketing is concerned with 'satisfying the needs have the customers by means of the product and the whole cluster of things associated with creating, delivering and finally consuming it'. To market effectively, information professionals must know their organization's business thoroughly to be able to contribute to its success (Levitt, 1986)

\section{Concept of Marketing in Library}

The history of marketing library began long before the concept was born. Samuel Swett Green in his often quoted speech at the ALA Conference in 1876 advocated "improved personal relations between librarians and readers". It could be said that today's marketing of library services has its roots in parts of the USA and Northern Europe, in countries with few illiterates and more money, libraries, and library schools than the rest of the world. This certainly does not mean that the idea of libraries reaching out to "the common man" has not occupied librarians in other parts of the world. For instance, there is the example of the "library movement" in India at the beginning of the 20th century (Renborg, 1997).

\section{Definition of Marketing}

The word marketing means different thing to different people.

National Association of Marketing Teachers (1935) "Marketing is the performance of business activities that direct the flow of goods and services from producer to consumers" (Gupta, 2008).

American Marketing Association (2004) “ Marketing is an organizational function and a set of processes for creating, communicating and delivering value to customers and for managing customer relationship in ways that benefit the organization and its stakeholders."

\section{Review of Related Literature}

Anil Kumar (2014) conducted a study has been undertaken to assess the marketing of information products \& services in Kurukshetra University library in the disciplines of social science. A well structured questionnaire was distributed among the research-scholars and teachers of seven departments viz History, Public administration, Social Work, Economics, psychology, Sociology, Political Science under the Social Science in K.U.K. The responses were gathered from 120 users (40 Teachers and 80 Research Scholars).The findings of the survey reveal useful facts about the marketing of information products \& services in kurukshetra university library.43.33\% of the respondents were always using the library daily, $14.16 \%$ sometimes and $14.16 \%$ respondents were usingthe library once in a week, $6.66 \%$ twice in a week. Only $20.83 \%$ respondents were using the library by occasionally. $94.16 \%$ respondents were use the library for research needs, $70.83 \%$ education purpose only. On the basis of the findings, it was suggested that in order to improve the library personnel should 
be made aware of the concepts and principles of modern marketing. So provide better provision for the library staff to attend in-service and career advancement courses and also most of the respondents were willing to pay for information products \& services imply that they rely on the quality of information products than the existing products, which were freely available. So kurukshetra university library have to restructure or develop some of the existing products and services and to start new services based on market analysis. Most of respondents were suggested that Kurukshetra University library should take necessary steps to install plasma or LCD screen in the library entrance hall to display notices and information (photographs, videos etc.) of their information services and products.

Abdul salami (2013) conducted a study of investigate marketing of library and information services prevalent in six geographical zones in Nigeria Polytechnic. The survey method was used for conducting the study, the instruments used for gathering data were questionnaire, observations and documentary sources. The librarians and students were sample using purposive sample techniques. The data collected was analyzed using frequency and percentages. The study reveals the information resources that were available in most polytechnics libraries as books, journals, pamphlets as well as information communication technology in most Polytechnics libraries, also library orientation and current awareness services were mostly used in marketing their resources and services. Recommendations, annual displays and exhibitions of resources were among resources recommended to library resources so as to attract users to library services.

Vij (2012) reviewed the studies which has been undertaken to discuss the development of information society, the libraries have also gone through a transformation. Libraries were much like a service industry where user satisfaction is supreme. The author dealt with the marketing of library products and services in India. Due to the pressure of growing technologies, expectations of users, high maintenance costs and reducing budget, the need of marketing of library products \& services has increased considerably. The marketing process of library products and services needed strategic planning. The major finding of the survey revealed to cover all those activities based on techniques, obstacles \& requirement of effective professional skills in marketing of library products and services in India.

Khan (2012) reviewed studies has been undertaken to explore different applications of social media for marketing of library and information resources and services. It investigated the respondent's attitude towards the usefulness of social media in marketing of library. A survey research method was administered by using a peerreviewed and pilot-tested questionnaire. Data were collected from librarians and LIS school academicians working at BahauddinZakariya University of Multan and the Islamia University of Bahawalpur. The major Findings showed that respondent's attitude was positive; majority agreed that the use of social media is important to capture the attention of online users and helps in distance learning and knowledge sharing. Respondents recommended the use of Facebook, Wikis, LinkedIn, Blogging, YouTube and online groups for marketing different library services. They indicated that inadequate training opportunities, lack of knowledge, privacy and identity theft, slow speed of internet and electricity failure were the problems for applying social media in libraries of Pakistan for marketing library resources and services. They demanded for trainings for social media usage and suggested that libraries should develop social media page for maximum exploitation of library services. The Study recommended that libraries should develop their marketing plan for utilizing social media for news and service alerts and quick updates to online users and fund raising.

Ansari (2010) reviewed studies have been undertaken to discuss faculty awareness \& find out new ways and means for the marketing of library \& information services and products in the digital era i.e. Marketing concepts, components of marketing in initial stage of marketing and basic skills necessary for it. Marketing oriented thought was necessity in today's competitive world in digital era. There was a competition not only among companies but also among nonprofit organizations. The study emphasized that the need of marketing, its trinity concept, usefulness in libraries, \& method of providing "LIBRARY AND INFORMATION PRODUCTS AND SERVICES", guidelines and implementation of marketing and the feedback mechanism for improvement in digital era has been discussed.

Shariful (2009) conducted a study on an article considered the concept of marketing in the light of library and information services and mention the necessity of marketing techniques in library and information centres. It provided an outline of the principles of information products/ services marketing and discussed the key steps of marketing for library and information centres. The article indicated the methods of applying marketing techniques to library and information centres and marketing difficulties to library and information services in developing countries were also discussed, with particular reference to those in Bangladesh.

Popoola (2008) Reviewed studies has been undertaken to discuss faculty awareness \& use of library information products and services in South West Nigeria Universities. Systematic random sampling method was used to select 446 faculty members from a population of 4,459 in the universities. A questionnaire formed the major instrument for data gathering. The response rate achieved was $89.7 \%$ and the reliability coefficient of the questionnaire used was $0.72 \%$. The study emphasized the idea that there was a significant difference in faculty awareness of available library products \& services. 
Nerisa (2008) reviewed studies has been undertaken to discuss electronic information resources and services offered by the J.D Rockefeller Research Library at Egerton University and the marketing of those resources. The author examined the various reasons for marketing information resources with emphasis on the various marketing strategies used by the J.D Rockefeller Research Library towards effective utilization of the available resources in supporting research, teaching and learning. The strategies include use of posters, notices, brochures, telephone calls, Current Awareness Services (CAS), workshops and seminars and decentralization of services among others. The study concluded with a discussion of cost effective use of those strategies in research and teaching.

AmritpalKaur (2007) Reviewed studies has been undertaken to assess the attitude of users towards the marketing of information services and products of university research libraries. A structured questionnaire was distributed among the library users of four universities of Punjab and Chandigarh. The responses were gathered from 1237 users (241 teachers, 271 research scholars and 725 postgraduate students). The major findings of the survey revealed useful facts about marketing of information products and services. More than $61 \%$ were willing to pay for developed information services and $57 \%$ for developed information products.

Kaur and Rani (2007) conducted a study on the Marketing of Information Products \& Services in University libraries of Punjab \& Chandigarh. The finding of the survey revealed useful facts about marketing of Information Products \& Services. In fact $61 \%$ of the respondents were willing to pay for the developed Information Services \& 57\% for developed Information Products and suggested that the library should adopt on appropriate marketing approach. Information centres enable the users to keep up with innovations by providing them various Information Services. Proper feedback mechanism was required to monitor the effectiveness of the services and products. Price charged for developed library services and products should be reasonable.

Spalding and Wang (2006) tried to explore how the Marketing concept was applied in practice to marketing academic library services through the experiences of academic libraries across USA. They focused on using marketing as a managerial tool to accomplish strategic organizational goals and objectives. In 2002-03 the Association of College \& Research Libraries (ACRL), in partnership with ALA, customized the ALA campaign for academic libraries of America. Many of the resources developed by ACRL were available over the WWW. The authors have tried to highlight the concepts incorporated in this campaign and have provided examples of how some academic libraries had customized for their use the concepts and resources to successfully meet local goals. The authors conclude that ACRL,S Academic Research Library campaign provided tools to assist librarian in better understanding their library users and the services they needed, incorporating this information into service improvement \& communicating more effectively what the library can deliver.

Sharma and Choudhary (2005) conducted a case study of All India Management Association (AIMA) Library. The authors found that experience of marketing of information services and products was very encouraging at the AIMA Library. The users' satisfaction assessment was overall good, which was evident from the fact that users were constantly asking for information through all possible means say e-mail, telephone, fax, mail and personal visits. Revenues generation of AIMA Library through products and services was also good and it was moving towards self sufficiency. The author's opinion that at present when library budgets were shrinking, marketing of its products was earnestly required.

Rajyalakshmi and Waghmare (2004) conducted a study on the concept of marketing, need for marketing of knowledge products and services in libraries in the present context, the activities which could be undertaken for marketing; different products which become financial resource generators for libraries. The ways and means of promotion; different methods of generation of finances in libraries, and some examples of charges collected for knowledge products and services were given and methods for price estimations for different services and products were discussed. It concluded by suggesting electronic information infrastructure has a great potential which the librarians and managers of information centers could utilize and become the potential finance resource generators for their sustainability, which would affect on growth and image of libraries and information professionals in India.

Kavulya (2004) conducted a study in the selected university libraries in Kenya revealed that regardless of the type, libraries were under pressure to justify their existence and funding through provision of customer or market-oriented services. That required a shift from product of service orientation to customer or need orientation. The study aimed isto identify the various types of library marketing covered out in the university libraries in Kenya. It also examined the methods used by university libraries in Kenya to market their services to different categories of users and the problems experienced therein. The population of the study consisted on six university libraries in the government sector and five in the private sector serving the academic community in Kenya. Among those two each from government sector and private sector were selected as sample. Data collected through interview using an interview schedule. The chief librarians of the selected universities were interviewed. Different marketing concepts provided libraries with the tools for collecting and analyzing useful data about information needs of customers, which assists in designing, developing and delivering appropriate services. The analysis revealed that there was a strong support for marketing of library resources. It concluded 
that, although efforts have been made to achieve this, more emphasis must be put on promotion of the already existing services and therefore on the need for university libraries in Kenya to adapt more systematic techniques in collecting data on their user needs, if they go to design and delivery services that fit user requirements.

Ekpenyong (2003) conducted a study of the marketing and promotion of information services in the University of Ibdan Library in Nigeria, now known as Kenneth Dike Library. It was a case study on the need to market information services to the target markets that were already available, namely: Lectures (teachers, researchers) students (undergraduates and post graduates), administrators and others (including national and international researchers). The analysis based on the statistics available from library records revealed that the library system has a big problem of reaching out to its target users. Lack of an effective marketing strategy of library resources has been found to be the main reason why targeted users- university teachers, researchers and students-are not using the library as they should. The study found that less than a quarter of those targeted users register annually in the library. A more aggressive marketing strategy has been set in place to sensitize users to the wealth of information resources available in the library.

Torres (2002) conducted a research study of marketing information services aimed at to determine the addressed how marketing efforts were integrated into training programmes for information professionals. What was done to promote the integration of marketing techniques in information service management and which marketing techniques were used to understand the environment of the service, met the needs of the users and non-users, optimize services and communicate effectively with the various sections of the public.

Martey (2000) conducted a study on marketing of information products and services of academic libraries. The author found that -the important variables involved in marketing the products and services of academic libraries. The importance of the quality of service and a focus on the customer was emphasized. Though inadequate funding may affect delivery of services, the academic librarian should be motivated by that challenge to plan and implement a marketing strategy to ensure heavy patronage. Heavy use determined the worth and survival of the library in the face of stiff competition from new and aggressive entrants into the information market place. It concluded with realities of the library situations in Ghana academic libraries obviously could market what was not available. They may not be in a position to provide quality services to users because of the serious problems of funding and retraining that Ghanaian librarians were struggling to solve. Suggested that however small the service was, there was a lot to be gained by embracing the marketing concept.

\section{Research Methodology}

For the purpose of the study, a questionnaire was designed (Appendix-1). The questionnaire was pretested before using it with the survey population. All the respondents were given the same questionnaire irrespective of their status. The questionnaire was distributed to any of the respondents who willingly agreed to participate in the study. The respondents were interviewed also to fill in the gaps, if any. A five point Likert scale has been used to know the users attitude towards marketing, level of satisfaction, and marketing statements.

\section{Data Collection}

The users' questionnaires were distributed personally to all the 40 respondents under various categories, viz. Scientists \& Research Scholars in all the disciplines of CSSRI Karnal. The respondents had to visit many times, particularly to the Scientists to collect the filled up questionnaires and in all the four departments it was collected. However, in spite of regular visits \& reminders not all the filled questionnaires could be received back. The following table shows questionnaires distributed $\&$ filled up received from both the category of users of all the disciplines of CSSRI karnal under the ICAR (Indian Council of Agricultural Research).

Population

\begin{tabular}{|c|l|c|c|}
\hline Sr. No & CSSRI Respondents & Questionnaires Distributed & Questionnaire Received \\
\hline $\mathbf{0 1}$ & Scientists & $35(87.5 \%)$ & $30(75.0 \%)$ \\
\hline $\mathbf{0 2}$ & Research Scholars & $05(12.5 \%)$ & $05(12.5 \%)$ \\
\hline \multicolumn{2}{|c|}{ Cumulative Total } & $40(100 \%)$ & $35(87.5 \%)$ \\
\hline
\end{tabular}

\section{Objectives of the Study}

The present study intends to investigate the following objectives:

* To examine and access the Information Products \& Services provided by the CSSRI, karnal in the disciplines of Agriculture Science. 
* To identify the Information needs of Scientists and Research Scholars and willingness to pay for the Information Products \& Services by Central Soil Salinity Research Institute in the disciplines of Agriculture science.

* To investigate the knowledge of awareness of Marketing of Information Product \& Services among the library users.

* To examine and understand the common problem faced by the users to access the Information Product \& Services in CSSRI library.

\section{Scope of the Study}

The study is being undertaken in order to identify the usability of Marketing of Information Products \& Services available in CSSRI karnal (under the ICAR) in the disciplines of Agriculture Science. The study will include Research Scholars \& Scientists of all the four departments viz, Soil and Crop Management, Irrigation and Drainage Engineering, Crop Improvement \& also Technology Evaluation and Transfer following under the Agricultural Science.

\section{Statement of the Problems}

Documentation activities of a country are very much interred linked with the research \& developmental efforts of the country. Research libraries spend huge amounts every year in building up their collections and offering library services. But these are of no use if these are not used to satisfy information needs of the library users. Effective utilization of resources and services can be achieved through marketing approach. It can assist them in the task of designing, developing and delivering appropriate services and products. Therefore, it is inevitable to know the attitudes towards marketing of information products \& services among the librarian and users. Thus, the topic of my research is "MARKETING OF INFORMATION PRODUCTS \& SERVICES BY THE RESEARCH SCHOLARS \& SCIENTISTS IN CENTRAL SOIL SALINITY RESEARCH INSTITUTE, KARNAL: A STUDY”.

$\underline{\text { Part- A Personal Profile }}$

\section{Analysis \& Interpretation}

Table 1. Gender wise Use the Library Products \&Services

\begin{tabular}{|c|l|c|}
\hline S.N & Gender wise & Response No \% \\
\hline 01 & Male & $29(82.85)$ \\
\hline 02 & Female & $6(17.14)$ \\
\hline Cumulative Total & $\mathbf{3 5}(\mathbf{1 0 0})$ \\
\hline
\end{tabular}

Table 1.shows that among Marketing of Information Products and Services in the CSSRI library male respondents were $82.85 \%$ and greater than female users which were $17.14 \%$.

Table 2. Status wise Use the library products \& services

\begin{tabular}{|c|l|c|}
\hline S.N & Status wise & Response No \% \\
\hline 01 & Scientists & $30(85.71)$ \\
\hline 02 & Research Scholars & $5(14.28)$ \\
\hline
\end{tabular}

Results in table 2. Show that marketing of Information Products and Services use the CSSRI library more popular Scientists than the Research Scholars. Out of total respondents $85.71 \%$ Scientists and $14.28 \%$ Research Scholars were used the library products and services.

\section{Part- B Library Use Pattern}

Table 3. Frequency of Use the Library

\begin{tabular}{|l|c|c|c|c|c|c|c|c|c|c|}
\hline \multirow{2}{*}{ Respondents } & \multicolumn{4}{|c|}{ Off- Line } & \multicolumn{5}{|c|}{ On-Line } \\
\cline { 2 - 11 } & Daily & Weekly & $\begin{array}{c}\text { Thrice } \\
\text { In a Week }\end{array}$ & Occasionally & Never & Daily & Weekly & $\begin{array}{c}\text { Thrice } \\
\text { In a Week }\end{array}$ & Occasionally & Never \\
\hline Scientists & - & - & $5(14.28)$ & $10(28.57)$ & - & $10(28.57)$ & $3(8.57)$ & $2(5.71)$ & - & - \\
\hline Research Scholars & $2(5.71)$ & - & - & - & - & $2(5.71)$ & $1(2.85)$ & - & - & - \\
\hline
\end{tabular}

Table 3.shows the respondents various availability available use the library. $14.28 \%$ respondents were used the off line library thrice in a Week, $5.71 \%$ daily and $28.57 \%$ occasionally. In fact $34.28 \%$ users were using the online library daily, $11.42 \%$ weekly and $5.71 \%$ Scientists thrice in a week use the online library. 
Table 4. Average time spent in the Library

\begin{tabular}{|l|c|c|c|c|c|c|c|c|c|c|}
\hline \multirow{3}{*}{ Respondents } & \multicolumn{4}{|c|}{ Off- Line } & \multicolumn{7}{c|}{ On-Line } \\
\cline { 2 - 12 } & $\begin{array}{c}\text { Less than } \\
\text { 30 Min. to 1 } \\
\text { Hour }\end{array}$ & $\begin{array}{c}\mathbf{1} \text { to 2 } \\
\text { Hours }\end{array}$ & $\begin{array}{c}\mathbf{2} \text { to 3 } \\
\text { Hours }\end{array}$ & $\begin{array}{c}\mathbf{3} \text { to 4 } \\
\text { Hours }\end{array}$ & $\begin{array}{c}\text { More than } \\
\mathbf{4} \text { Hours }\end{array}$ & $\begin{array}{c}\text { Less than } \\
\mathbf{3 0} \text { Min. to 1 } \\
\text { Hour }\end{array}$ & $\begin{array}{c}\mathbf{1} \text { to 2 } \\
\text { Hours }\end{array}$ & $\begin{array}{c}\mathbf{2} \text { to 3 } \\
\text { Hours }\end{array}$ & $\begin{array}{c}\mathbf{3} \text { to 4 } \\
\text { Hours }\end{array}$ & $\begin{array}{c}\text { More than } \\
\mathbf{4} \text { Hours }\end{array}$ \\
\hline Scientists & - & $8(22.85)$ & - & - & - & - & $2(5.71)$ & $6(17.14)$ & $5(14.28)$ & $9(25.71)$ \\
\hline Research Scholars & $1(2.85)$ & - & - & - & & - & - & $1(2.85)$ & $3(8.57)$ & - \\
\hline
\end{tabular}

Table 4.shows that Agricultural Scienceusers i.e. Scientists and Research Scholars were mostly spend time on the offline and online CSSRI library. Only $2.85 \%$ respondents spend less than 30 minutes to 1 hour and $22.85 \%$ 1 to 2 hours regarding offline time in the library on a visit. In fact $25.71 \%$ users were using the on-line library bymore than 4 hours, $22.85 \%$ Scientists and Research Scholars both were 3 to 4 hours and also $20 \%$ respondents 2 to 3 hours time spend in the online library. Central Soil SalinityResearch Institute Scientists only $5.71 \% 1$ to 2 hourstime spend by online library.

Table 5. Purpose do you use the Library

\begin{tabular}{|c|l|c|c|c|c|c|c|c|}
\hline S. N & Respondents & Teaching & $\begin{array}{c}\text { Research } \\
\text { Work }\end{array}$ & Entertainment & $\begin{array}{c}\text { Updating } \\
\text { Knowledge }\end{array}$ & Education & $\begin{array}{c}\text { Writing Paper \& } \\
\text { Presenting paper }\end{array}$ & Translation \\
\hline 01 & Scientists & $10(28.57)$ & $30(85.71)$ & $3(8.57)$ & $20(57.14)$ & $8(22.85)$ & $30(85.71)$ & - \\
\hline 02 & Research Scholars & $2(5.71)$ & $5(14.28)$ & $2(5.71)$ & $5(14.28)$ & - & $5(14.28)$ & - \\
\hline \multicolumn{2}{|c|}{ Cumulative Total } & $12(34.28)$ & $35(100)$ & $5(14.28)$ & $25(71.42)$ & $8(22.85)$ & $35(100)$ & - \\
\hline
\end{tabular}

Most of the respondents use the library for more than one purpose. The analysis shows that main purpose of use the library were Research Work \& Writing Paper/ presenting paper. In Central Soil Salinity Research Institute respondents i.e. Scientists and Research Scholars were100\%using the library for the purpose of Research work $\&$ Writing/Presenting paper, and update knowledge were the second purpose for which users use the library i.e. $71.42 \%$. The third purpose for used the library i.e. $34.28 \%$ users were teaching and $22.85 \%$ education regarding which used the library by Scientists on CSSRI, Karnal. In agricultural science i.e. CSSRI only14.28\% respondents were positively using the library for entertainment only.

Table 6. Regarding Reason for not using the library regularly

\begin{tabular}{|c|l|c|c|c|c|c|c|c|}
\hline S. N & Respondents & $\begin{array}{c}\text { Lack of } \\
\text { time }\end{array}$ & $\begin{array}{c}\text { Get Information } \\
\text { elsewhere or Online }\end{array}$ & $\begin{array}{c}\text { Inconvenient } \\
\text { working hours }\end{array}$ & $\begin{array}{c}\text { Inconvenient } \\
\text { location }\end{array}$ & $\begin{array}{c}\text { Insufficient } \\
\text { Material }\end{array}$ & $\begin{array}{c}\text { Lack of } \\
\text { trained staff }\end{array}$ & $\begin{array}{c}\text { Library staff is } \\
\text { not helpful }\end{array}$ \\
\hline 01 & Scientists & $5(14.28)$ & $15(42.85)$ & - & - & - & - & - \\
\hline 02 & Research Scholars & $1(2.85)$ & $2(5.71)$ & - & - & - & - & - \\
\hline \multicolumn{2}{r|}{ Cumulative Total } & $6(17.14)$ & $17(48.57)$ & & & & & - \\
\hline
\end{tabular}

Data given in table 6 indicates that $17.14 \%$ of respondents identified the main reason for not using the library regularly is that they get lack of time $17.14 \%$ followed by get information elsewhere or online $48.57 \%$.

\section{$\underline{\text { Part- C Marketing of Information Products \& Services }}$}

Table 7. Information Services that you need to find

\begin{tabular}{|c|c|c|c|c|}
\hline S. $\mathbf{N}$ & Information Services & Respondents & $\%$ & Cumulative total \\
\hline \multirow[t]{2}{*}{01} & \multirow[t]{2}{*}{ Current Awareness Services } & Scientists & $10(28.57)$ & \multirow[b]{2}{*}{$13(37.14)$} \\
\hline & & Research Scholars & $3(8.57)$ & \\
\hline \multirow[t]{2}{*}{02} & \multirow[t]{2}{*}{ Newspaper clippings } & Scientists & - & \multirow[b]{2}{*}{-} \\
\hline & & Research Scholars & - & \\
\hline \multirow[t]{2}{*}{03} & \multirow[t]{2}{*}{ Indexing/Abstracting Services } & Scientists & - & \multirow[b]{2}{*}{ - } \\
\hline & & Research Scholars & - & \\
\hline \multirow[t]{2}{*}{04} & \multirow[t]{2}{*}{ Translation Services } & Scientists & $5(14.28)$ & \multirow[b]{2}{*}{$5(14.28)$} \\
\hline & & Research Scholars & - & \\
\hline \multirow[t]{2}{*}{05} & \multirow[t]{2}{*}{ Literature Search } & Scientists & $25(71.42)$ & \multirow[b]{2}{*}{$30(85.71)$} \\
\hline & & Research Scholars & $5(14.28)$ & \\
\hline
\end{tabular}


Marketing of Information Products \& Services by the Research Scholars \& Scientists in Central Soil

\begin{tabular}{|c|c|c|c|c|}
\hline \multirow[t]{2}{*}{06} & \multirow[t]{2}{*}{ Photocopying of Periodical Articles } & Scientists & $10(28.57)$ & \multirow[b]{2}{*}{$13(37.14)$} \\
\hline & & Research Scholars & $3(8.57)$ & \\
\hline \multirow{2}{*}{07} & \multirow{2}{*}{ Selective Dissemination of Information } & Scientists & - & \multirow[b]{2}{*}{-} \\
\hline & & Research Scholars & - & \\
\hline \multirow{2}{*}{08} & \multirow{2}{*}{ Circulation of Periodical Content } & Scientists & - & \multirow[b]{2}{*}{-} \\
\hline & & Research Scholars & - & \\
\hline \multirow{2}{*}{09} & \multirow{2}{*}{ Reference Services } & Scientists & $20(57.14)$ & \multirow[b]{2}{*}{$22(62.85)$} \\
\hline & & Research Scholars & $2(5.71)$ & \\
\hline \multirow{2}{*}{10} & \multirow{2}{*}{ Inter Library Loan } & Scientists & - & \multirow[b]{2}{*}{-} \\
\hline & & Research Scholars & - & \\
\hline \multirow{2}{*}{11} & \multirow{2}{*}{ Repacking \& Condensation Service } & Scientists & - & \multirow[b]{2}{*}{-} \\
\hline & & Research Scholars & - & \\
\hline \multirow{2}{*}{12} & \multirow{2}{*}{ Any Others } & Scientists & & \multirow[b]{2}{*}{-} \\
\hline & & Research Scholars & & \\
\hline
\end{tabular}

Users may use the Information Services for a variety of reasons. The need of using Information Services differs from one user to another. It can be seen from Table No 7. that $37.14 \%$ respondents were using the Current Awareness Services and $14.28 \%$ translation services about the subject of interestneed. The study shows that CSSRI respondents were maximum using the information services which $85.71 \%$ literature search while $37.14 \%$ photocopying of periodical articles. It has been found that $62.85 \%$ respondents make always use of reference services for the information need required the subject of interest positively.

Table 8. Information Products that you need to find

\begin{tabular}{|c|c|c|c|c|}
\hline S. $\mathbf{N}$ & Information Services & Respondents & $\%$ & Cumulative total \\
\hline \multirow[t]{2}{*}{01} & \multirow[t]{2}{*}{ Subject books } & Scientists & $20(57.14)$ & \multirow[b]{2}{*}{$25(71.42)$} \\
\hline & & Research Scholars & $05(14.28)$ & \\
\hline \multirow[t]{2}{*}{02} & \multirow[t]{2}{*}{ Information Bulletin } & Scientists & $10(28.57)$ & \multirow{2}{*}{$13(37.14)$} \\
\hline & & Research Scholars & $03(8.57)$ & \\
\hline \multirow[t]{2}{*}{03} & \multirow[t]{2}{*}{ Reprints } & Scientists & $25(71.42)$ & \multirow{2}{*}{$25(71.42)$} \\
\hline & & Research Scholars & - & \\
\hline \multirow[t]{2}{*}{04} & \multirow[t]{2}{*}{ Online Products } & Scientists & $20(57.14)$ & \multirow{2}{*}{$24(68.57)$} \\
\hline & & Research Scholars & $04(11.42)$ & \\
\hline \multirow[t]{2}{*}{05} & \multirow[t]{2}{*}{ Review } & Scientists & $10(28.57)$ & \multirow{2}{*}{$10(28.57)$} \\
\hline & & Research Scholars & - & \\
\hline \multirow[t]{2}{*}{06} & \multirow[t]{2}{*}{ Index } & Scientists & - & \multirow[b]{2}{*}{ - } \\
\hline & & Research Scholars & - & \\
\hline \multirow{2}{*}{07} & \multirow{2}{*}{ Abstracts Lists } & Scientists & - & \multirow[b]{2}{*}{-} \\
\hline & & Research Scholars & - & \\
\hline \multirow{2}{*}{08} & \multirow{2}{*}{ Reference Books } & Scientists & $10(28.57)$ & \multirow{2}{*}{$13(37.14)$} \\
\hline & & Research Scholars & $03(8.57)$ & \\
\hline \multirow{2}{*}{09} & \multirow{2}{*}{ Standards/Patents } & Scientists & - & \multirow[b]{2}{*}{ - } \\
\hline & & Research Scholars & - & \\
\hline \multirow{2}{*}{10} & \multirow{2}{*}{ Thesis/Dissertation } & Scientists & - & \multirow{2}{*}{$05(14.28)$} \\
\hline & & Research Scholars & $05(14.28)$ & \\
\hline \multirow{2}{*}{11} & \multirow{2}{*}{ Current Awareness Bulletins } & Scientists & - & \\
\hline & & Research Scholars & - & - \\
\hline & & Scientists & $18(51.42)$ & \\
\hline 12 & Monographs & Research Scholars & - & $18(51.42)$ \\
\hline & & Scientists & - & \\
\hline 13 & Bibliographic Lists & Research Scholars & - & - \\
\hline & & Scientists & - & \\
\hline 14 & Any Uther & Research Scholars & - & - \\
\hline
\end{tabular}


To survey the users'needs regarding information products, fourteen types of information products were identified and formulated. The responses analyzed in table 8 reveal that more than $71.42 \%$ of the respondents want subject books and reprints. In fact $37.14 \%$ respondents want need of information products i.e. reference books and information bulletin.All the other products required by the respondents have been given in table 9 in order of preference.

Table 9. Awareness of Information Products \& Services in the Library

\begin{tabular}{|c|c|c|c|c|c|}
\hline S. $\mathbf{N}$ & $\begin{array}{l}\text { Information Products \& } \\
\text { Services }\end{array}$ & Respondents & $\begin{array}{l}\text { Aware of \& } \\
\text { Used }\end{array}$ & $\begin{array}{l}\text { Aware of } \\
\text { but not used }\end{array}$ & $\begin{array}{l}\text { Not aware } \\
\text { of }\end{array}$ \\
\hline \multirow[t]{2}{*}{01} & \multirow[t]{2}{*}{ Indexing Service } & Scientists & - & $30(85.71)$ & - \\
\hline & & Research Scholars & - & $5(14.28)$ & - \\
\hline \multirow[t]{2}{*}{02} & \multirow{2}{*}{ Abstracting Service } & Scientists & - & $30(85.71)$ & - \\
\hline & & Research Scholars & - & $05(14.28)$ & - \\
\hline \multirow[t]{2}{*}{03} & \multirow{2}{*}{ Bibliographic Service } & Scientists & $20(57.14)$ & $10(28.57)$ & - \\
\hline & & Research Scholars & $5(14.28)$ & - & - \\
\hline \multirow[t]{2}{*}{04} & \multirow{2}{*}{$\begin{array}{l}\text { SDI (Selective Dissemination } \\
\text { of Information) }\end{array}$} & Scientists & - & - & $30(85.71)$ \\
\hline & & Research Scholars & - & - & $05(14.28)$ \\
\hline \multirow[t]{2}{*}{05} & \multirow{2}{*}{ Current Awareness Service } & Scientists & $20(57.14)$ & $10(28.57)$ & - \\
\hline & & Research Scholars & $03(8.57)$ & $02(5.71)$ & - \\
\hline \multirow[t]{2}{*}{06} & \multirow[b]{2}{*}{ Newspaper Clippings } & Scientists & - & $30(85.71)$ & - \\
\hline & & Research Scholars & - & $05(14.28)$ & - \\
\hline \multirow{2}{*}{07} & \multirow[b]{2}{*}{ Consultancy Services } & Scientists & - & $05(14.28)$ & $20(57.14)$ \\
\hline & & Research Scholars & - & - & $05(14.28)$ \\
\hline \multirow{2}{*}{08} & \multirow{2}{*}{ Reprographic Service } & Scientists & $30(85.71)$ & - & - \\
\hline & & Research Scholars & $05(14.28)$ & - & - \\
\hline \multirow{2}{*}{09} & \multirow{2}{*}{ Reprints/Pre-Print Services } & Scientists & $30(85.71)$ & - & - \\
\hline & & Research Scholars & $05(14.28)$ & - & - \\
\hline \multirow{2}{*}{10} & \multirow{2}{*}{ Document Delivery Service } & Scientists & $10(28.57)$ & $20(57.14)$ & - \\
\hline & & Research Scholars & - & $05(14.28)$ & - \\
\hline \multirow{2}{*}{11} & \multirow{2}{*}{ Translation Service } & Scientists & - & $30(85.71)$ & - \\
\hline & & Research Scholars & - & $05(14.28)$ & - \\
\hline \multirow{2}{*}{12} & & Scientists & - & $10(28.57)$ & $20(57.14)$ \\
\hline & Inter Library Loan service & Research Scholars & - & $01(2.85)$ & $04(11.42)$ \\
\hline & & Scientists & $30(85.71)$ & - & - \\
\hline 13 & Internet Service & Research Scholars & $05(14.28)$ & - & - \\
\hline & & Scientists & - & $30(85.71)$ & - \\
\hline 14 & Document Scanning/Printing & Research Scholars & - & $05(14.28)$ & - \\
\hline & & Scientists & $30(85.71)$ & - & - \\
\hline 15 & Literature Searching & Research Scholars & $05(14.28)$ & - & - \\
\hline 16 & Enquiry Services & Scientists & $20(57.14)$ & $10(28.57)$ & - \\
\hline 10 & & Research Scholars & $05(14.28)$ & - & - \\
\hline 17 & Donolkaino \&- Condonotion & Scientists & - & - & $30(85.71)$ \\
\hline 17 & Kepackaging \& Condensation & Research Scholars & - & - & $05(14.28)$ \\
\hline & & Scientists & $15(42.85)$ & $15(42.85)$ & - \\
\hline 18 & Monograpns & Research Scholars & - & $05(14.28)$ & - \\
\hline & & Scientists & $10(28.57)$ & $20(57.14)$ & - \\
\hline 19 & Review & Research Scholars & $01(2.85)$ & $04(11.42)$ & - \\
\hline & & Scientists & - & $30(85.71)$ & - \\
\hline 20 & $\begin{array}{l}\text { Circulation of } \\
\text { Contents }\end{array}$ Periodical & Research Scholars & - & $05(14.28)$ & - \\
\hline & & Scientists & $10(28.57)$ & $20(57.14)$ & - \\
\hline 21 & Govt./Institute Publications & Research Scholars & $02(5.71)$ & $03(8.57)$ & - \\
\hline & & Scientists & $12(34.28)$ & $18(51.42)$ & - \\
\hline 22 & Patents & Research Scholars & - & $05(14.28)$ & - \\
\hline 23 & & Scientists & - & $30(85.71)$ & - \\
\hline
\end{tabular}


Marketing of Information Products \& Services by the Research Scholars \& Scientists in Central Soil

\begin{tabular}{|l|l|l|c|c|c|}
\hline & Standards & Research Scholars & - & $05(14.28)$ & - \\
\hline \multirow{2}{*}{24} & \multirow{2}{*}{ CD ROM Database } & Scientists & $10(28.57)$ & $20(57.14)$ & - \\
\cline { 3 - 6 } & & Research Scholars & $05(14.28)$ & - & - \\
\hline \multirow{2}{*}{25} & \multirow{2}{*}{ Online E-Resources } & Scientists & $16(45.71)$ & $14(40.0)$ & - \\
\cline { 3 - 6 } & & Research Scholars & $05(14.28)$ & - & - \\
\hline
\end{tabular}

Twenty five were identified to know the ways through which respondents keep themselves up to date with the information in their field of interest. It is revealed from Table 9. that $100 \%$ of the respondents keep themselves aware of \& used through reprographic, reprints, internet, literature search, and $71.42 \%$ by bibliographic, enquiry services and also $100 \%$ respondents aware of, but not used by indexing, abstracting, newspaper, translation, document scanning/printing, circulation of periodical contents, standards. In fact CSSRI 100\% users were not aware of SDI (Selective Dissemination of Information), repacking \& condensation. The other ways in order of preference have been given in table 9 .

Table 10. Frequency to Access of Information Products \& Services in the Library

\begin{tabular}{|c|c|c|c|c|c|c|c|}
\hline S. N & $\begin{array}{l}\text { Information Products \& } \\
\text { Services }\end{array}$ & Respondents & Always & Often & Usually & Sometimes & Never \\
\hline \multirow[t]{2}{*}{01} & \multirow[t]{2}{*}{ Indexing Service } & Scientists & - & - & - & - & $30(85.71)$ \\
\hline & & Research Scholars & - & - & - & - & $05(14.28)$ \\
\hline \multirow[t]{2}{*}{02} & \multirow{2}{*}{ Abstracting Service } & Scientists & - & - & - & - & $30(85.71)$ \\
\hline & & Research Scholars & - & - & - & - & $05(14.28)$ \\
\hline \multirow[t]{2}{*}{03} & \multirow{2}{*}{ Bibliographic Service } & Scientists & $10(28.57)$ & $10(28.57)$ & - & - & $10(28.57)$ \\
\hline & & Research Scholars & $03(8.57)$ & $02(5.71)$ & - & - & - \\
\hline \multirow[t]{2}{*}{04} & \multirow{2}{*}{$\begin{array}{l}\text { SDI (Selective Dissemination } \\
\text { of Information) }\end{array}$} & Scientists & - & - & - & - & $30(85.71)$ \\
\hline & & Research Scholars & - & - & - & - & $05(14.28)$ \\
\hline \multirow[t]{2}{*}{05} & \multirow[b]{2}{*}{ Current Awareness Service } & Scientists & $10(28.57)$ & $05(14.28)$ & $5(14.28)$ & - & $10(28.57)$ \\
\hline & & Research Scholars & - & - & - & $03(8.57)$ & $02(5.71)$ \\
\hline \multirow[t]{2}{*}{06} & \multirow{2}{*}{ Newspaper Clippings } & Scientists & - & - & - & - & $30(85.71)$ \\
\hline & & Research Scholars & - & - & - & - & $05(14.28)$ \\
\hline \multirow[b]{2}{*}{07} & \multirow[b]{2}{*}{ Consultancy Services } & Scientists & - & - & - & - & $30(85.71)$ \\
\hline & & Research Scholars & - & - & - & - & $05(14.28)$ \\
\hline \multirow{2}{*}{08} & \multirow{2}{*}{ Reprographic Service } & Scientists & $25(71.42)$ & $05(14.28)$ & - & - & - \\
\hline & & Research Scholars & - & $05(14.28)$ & - & - & - \\
\hline \multirow{2}{*}{09} & \multirow{2}{*}{ Reprints/Pre-Print Services } & Scientists & $25(71.42)$ & $05(14.28)$ & - & - & - \\
\hline & & Research Scholars & - & $05(14.28)$ & - & - & - \\
\hline \multirow{2}{*}{10} & \multirow{2}{*}{ Document Delivery Service } & Scientists & - & - & - & $10(28.57)$ & $20(57.14)$ \\
\hline & & Research Scholars & - & - & - & - & $05(14.28)$ \\
\hline \multirow{2}{*}{11} & \multirow{2}{*}{ Translation Service } & Scientists & - & - & - & - & $30(85.71)$ \\
\hline & & Research Scholars & - & - & - & - & $05(14.28)$ \\
\hline \multirow{2}{*}{12} & \multirow{2}{*}{ Inter Library Loan Service } & Scientists & - & - & - & - & $30(85.71)$ \\
\hline & & Research Scholars & - & - & - & - & $05(14.28)$ \\
\hline \multirow{2}{*}{13} & \multirow[b]{2}{*}{ Internet Service } & Scientists & $30(85.71)$ & - & - & - & - \\
\hline & & Research Scholars & $05(14.28)$ & - & - & - & - \\
\hline & & Scientists & - & - & - & - & $30(85.71)$ \\
\hline 14 & Document Scanning/Printing & Research Scholars & - & - & - & - & $05(14.28)$ \\
\hline & & Scientists & $20(57.14)$ & $10(28.57)$ & - & - & - \\
\hline 15 & Literature Searching & Research Scholars & $05(14.28)$ & - & - & - & - \\
\hline & Enquiry Services & Scientists & - & - & - & $20(57.14)$ & $10(28.57)$ \\
\hline 16 & & Research Scholars & - & - & - & $05(14.28)$ & - \\
\hline & & Scientists & - & - & - & - & $30(85.71)$ \\
\hline 17 & Repackaging \& Condensation & Research Scholars & - & - & - & - & $05(14.28)$ \\
\hline & & Scientists & $15(42.85)$ & - & - & - & $15(42.85)$ \\
\hline 18 & Monographs & Research Scholars & - & - & - & - & $05(14.28)$ \\
\hline 19 & & Scientists & - & - & - & $10(28.57)$ & $20(57.14)$ \\
\hline
\end{tabular}


Marketing of Information Products \& Services by the Research Scholars \& Scientists in Central Soil

\begin{tabular}{|c|c|c|c|c|c|c|c|}
\hline & Review & Research Scholars & - & - & - & $01(2.85)$ & $04(11.42)$ \\
\hline \multirow[b]{2}{*}{20} & \multirow[b]{2}{*}{$\begin{array}{l}\text { Circulation of Periodical } \\
\text { Contents }\end{array}$} & Scientists & - & - & - & - & $30(85.71)$ \\
\hline & & Research Scholars & - & - & - & - & $05(14.28)$ \\
\hline \multirow[t]{2}{*}{21} & \multirow[t]{2}{*}{ Govt./Institute Publications } & Scientists & - & - & $\begin{array}{c}10 \\
(28.57) \\
\end{array}$ & - & $20(57.14)$ \\
\hline & & Research Scholars & & & $02(5.71)$ & - & $03(8.57)$ \\
\hline \multirow{2}{*}{22} & \multirow[b]{2}{*}{ Patents } & Scientists & - & - & - & $12(34.28)$ & $18(34.28)$ \\
\hline & & Research Scholars & & & & - & $05(14.28)$ \\
\hline \multirow{2}{*}{23} & \multirow[b]{2}{*}{ Standards } & Scientists & - & - & - & - & $30(85.71)$ \\
\hline & & Research Scholars & - & - & - & - & $05(14.28)$ \\
\hline \multirow[b]{2}{*}{24} & \multirow[t]{2}{*}{ CD ROM Database } & Scientists & - & - & $\begin{array}{c}10 \\
(28.57)\end{array}$ & - & $20(57.14)$ \\
\hline & & Research Scholars & - & - & $\begin{array}{c}05 \\
(14.28) \\
\end{array}$ & - & - \\
\hline \multirow[b]{2}{*}{25} & \multirow[b]{2}{*}{ Online E-Resources } & Scientists & $16(45.71)$ & - & - & - & $14(40.0)$ \\
\hline & & Research Scholars & $05(14.28)$ & - & - & - & - \\
\hline
\end{tabular}

Table 10. shows that $100 \%$ of the respondents have never access the library products \&services among which includesindexing, abstracting, SDI, newspaper, consultancy, translation, Inter library loan, document scanning/printing, repacking \& condensation, circulation of periodical content, standard and $100 \%$ havealways access the library services i.e. internet. More than $71.42 \%$ respondents were using the always access the reprographic, reprints, literature searching services and $28.57 \%$ often. Only $37.14 \%$ respondents were always access the bibliographic servicesthen $34.28 \%$ often and $28.57 \%$ never access. In fact $60 \%$ CSSRI respondents were always access the online E-Resources and $40 \%$ neveraccess .Even though digital services such as CD ROM database only $42.85 \%$ Scientists and Research Scholars were usually access the Information and $57.14 \%$ never access. The other ways in order of preference have been given in table 10 .

Table 11. Willingness to Pay for Information Products \& Services in the Library

\begin{tabular}{|c|c|c|c|c|}
\hline \multirow[t]{2}{*}{ S. $\mathbf{N}$} & \multirow[t]{2}{*}{ Information Products \& Services } & \multirow[t]{2}{*}{ Respondents } & \multicolumn{2}{|c|}{ Willingness to Pay } \\
\hline & & & Free Base & Fee Base \\
\hline \multirow[t]{2}{*}{01} & \multirow[t]{2}{*}{ Indexing Service } & Scientists & $30(85.71)$ & - \\
\hline & & Research Scholars & $05(14.28)$ & - \\
\hline \multirow[t]{2}{*}{02} & \multirow{2}{*}{ Abstracting Service } & Scientists & $30(85.71)$ & - \\
\hline & & Research Scholars & $05(14.28)$ & - \\
\hline \multirow[t]{2}{*}{03} & \multirow{2}{*}{ Bibliographic Service } & Scientists & $30(85.71)$ & - \\
\hline & & Research Scholars & $05(14.28)$ & - \\
\hline \multirow[t]{2}{*}{04} & \multirow[b]{2}{*}{ SDI (Selective Dissemination of Information) } & Scientists & $30(85.71)$ & - \\
\hline & & Research Scholars & $05(14.28)$ & - \\
\hline \multirow[t]{2}{*}{05} & \multirow{2}{*}{ Current Awareness Service } & Scientists & $30(85.71)$ & - \\
\hline & & Research Scholars & $05(14.28)$ & - \\
\hline \multirow[t]{2}{*}{06} & \multirow[b]{2}{*}{ Newspaper Clippings } & Scientists & $30(85.71)$ & - \\
\hline & & Research Scholars & $05(14.28)$ & - \\
\hline \multirow{2}{*}{07} & \multirow[b]{2}{*}{ Consultancy Services } & Scientists & $30(85.71)$ & - \\
\hline & & Research Scholars & $05(14.28)$ & - \\
\hline \multirow{2}{*}{08} & \multirow{2}{*}{ Reprographic Service } & Scientists & $30(85.71)$ & - \\
\hline & & Research Scholars & $05(14.28)$ & - \\
\hline \multirow{2}{*}{09} & \multirow{2}{*}{ Reprints/Pre-Print Services } & Scientists & $30(85.71)$ & - \\
\hline & & Research Scholars & $05(14.28)$ & - \\
\hline \multirow{2}{*}{10} & \multirow{2}{*}{ Document Delivery Service } & Scientists & $30(85.71)$ & - \\
\hline & & Research Scholars & $05(14.28)$ & - \\
\hline \multirow{2}{*}{11} & \multirow{2}{*}{ Translation Service } & Scientists & $30(85.71)$ & - \\
\hline & & Research Scholars & $05(14.28)$ & - \\
\hline \multirow{2}{*}{12} & \multirow{2}{*}{ Inter Library Loan Service } & Scientists & $30(85.71)$ & - \\
\hline & & Research Scholars & $05(14.28)$ & - \\
\hline 13 & & Scientists & $30(85.71)$ & - \\
\hline
\end{tabular}


Marketing of Information Products \& Services by the Research Scholars \& Scientists in Central Soil

\begin{tabular}{|c|c|c|c|c|}
\hline & Internet Service & Research Scholars & $05(14.28)$ & - \\
\hline \multirow{2}{*}{14} & \multirow{2}{*}{ Document Scanning/Printing } & Scientists & $30(85.71)$ & - \\
\hline & & Research Scholars & $05(14.28)$ & - \\
\hline \multirow{2}{*}{15} & \multirow{2}{*}{ Literature Searching } & Scientists & $30(85.71)$ & - \\
\hline & & Research Scholars & $05(14.28)$ & - \\
\hline \multirow{2}{*}{16} & \multirow[t]{2}{*}{ Enquiry Services } & Scientists & $30(85.71)$ & - \\
\hline & & Research Scholars & $05(14.28)$ & - \\
\hline \multirow{2}{*}{17} & \multirow{2}{*}{ Repackaging \& Condensation } & Scientists & $30(85.71)$ & - \\
\hline & & Research Scholars & $05(14.28)$ & - \\
\hline \multirow{2}{*}{18} & \multirow{2}{*}{ Monographs } & Scientists & $30(85.71)$ & - \\
\hline & & Research Scholars & $05(14.28)$ & - \\
\hline \multirow{2}{*}{19} & \multirow[b]{2}{*}{ Review } & Scientists & $30(85.71)$ & - \\
\hline & & Research Scholars & $05(14.28)$ & - \\
\hline \multirow{2}{*}{20} & \multirow{2}{*}{ Circulation of Periodical Contents } & Scientists & $30(85.71)$ & - \\
\hline & & Research Scholars & $05(14.28)$ & - \\
\hline \multirow{2}{*}{21} & \multirow{2}{*}{ Govt./Institute Publications } & Scientists & $30(85.71)$ & - \\
\hline & & Research Scholars & $05(14.28)$ & - \\
\hline \multirow[b]{2}{*}{22} & \multirow[b]{2}{*}{ Patents } & Scientists & $30(85.71)$ & - \\
\hline & & Research Scholars & $05(14.28)$ & - \\
\hline \multirow{2}{*}{23} & \multirow{2}{*}{ Standards } & Scientists & $30(85.71)$ & - \\
\hline & & Research Scholars & $05(14.28)$ & - \\
\hline \multirow[b]{2}{*}{24} & \multirow[b]{2}{*}{ CD ROM Database } & Scientists & $30(85.71)$ & - \\
\hline & & Research Scholars & $05(14.28)$ & - \\
\hline \multirow{2}{*}{25} & \multirow{2}{*}{ Online E-Resources } & Scientists & $30(85.71)$ & - \\
\hline & & Research Scholars & $05(14.28)$ & - \\
\hline
\end{tabular}

It is revealed from Table 11. that a majority of the $100 \%$ respondents were free of cost all the CSSRI library products and services.

Table 12. Online Database

\begin{tabular}{|c|l|c|c|}
\hline Sr. No & Respondents & Yes & No \\
\hline 01 & Scientists & $20(57.14)$ & $10(28.57)$ \\
\hline 02 & Research Scholars & $05(14.28)$ & - \\
\hline Cumulative Total & $25(71.42)$ & $10(28.57)$ \\
\hline
\end{tabular}

The use of online database is the need of the hour of the present days. Table No 12. Shows the access about online database were among the Scientists \& Research Scholars. The respondents were asked about access of online database. It was found that $71.42 \%$ users have access the online database relating in your subject field and then only $28.57 \%$ never used it.

Table 13.Online Database relating in your subject field

\begin{tabular}{|c|l|c|c|c|c|c|}
\hline Sr. No & Respondents & $\begin{array}{c}\text { NARD- National } \\
\text { Agricultural } \\
\text { Research Database }\end{array}$ & $\begin{array}{c}\text { CERA- Consortium } \\
\text { for E-Resources } \\
\text { in Agriculture }\end{array}$ & $\begin{array}{c}\text { NKRC- National } \\
\text { Knowledge Resources } \\
\text { Consortium }\end{array}$ & $\begin{array}{c}\text { AGRIS- Agricultural } \\
\text { Information } \\
\text { System }\end{array}$ & Krishi Kosh \\
\hline 01 & Scientists & - & $20(57.14)$ & - & - & $10(28.57)$ \\
\hline 02 & Research Scholars & - & $05(14.28)$ & - & - & $03(8.57)$ \\
\hline \multicolumn{2}{l|}{ Cumulative Total } & - & $25(71.42)$ & & & $13(37.14)$ \\
\hline
\end{tabular}

Table 13. shows that majority of $71.42 \%$ respondents reported that the CERAwas usedand $37.14 \%$ of the users were using the KrishiKosh database relating in your subject field of interest. 
Table 14. You are able to keep up yourself with Innovations in your field

\begin{tabular}{|c|l|c|c|c|c|c|}
\hline Sr. No & Respondents & $\begin{array}{c}\text { To a very great } \\
\text { extent }\end{array}$ & $\begin{array}{c}\text { To a great } \\
\text { extent }\end{array}$ & $\begin{array}{c}\text { To a considerable } \\
\text { extent }\end{array}$ & $\begin{array}{c}\text { To a moderate } \\
\text { extent }\end{array}$ & $\begin{array}{c}\text { To some } \\
\text { extent }\end{array}$ \\
\hline 01 & Scientists & $10(28.57)$ & $20(57.14)$ & - & - & - \\
\hline 02 & Research Scholars & - & $03(8.57)$ & $02(5.71)$ & - & - \\
\hline Cumulative Total & $10(28.57)$ & $23(65.71)$ & $02(5.71)$ & & \\
\hline
\end{tabular}

For this purpose five degrees of keep up yourself with innovations in your field of interest were identified and formulated. Table No. 14 shows that a majority of the respondents i.e. $65.71 \%$ were able to keep up yourself with innovations in your field to a great extent, $28.57 \%$ respondents were to a very great extent and $5.71 \%$ to a considerable extent.

Table 15. Common Problem faced by you to access the Information Resources

\begin{tabular}{|c|c|c|c|c|}
\hline Sr. No & $\begin{array}{l}\text { Common Problem faced by you to access the Information } \\
\text { Resources }\end{array}$ & Respondents & Percentage & $\begin{array}{l}\text { Cumulative } \\
\text { Total }\end{array}$ \\
\hline \multirow[t]{2}{*}{01} & \multirow[t]{2}{*}{ Lack of Information Technology } & Scientists & $05(14.28)$ & \multirow[t]{2}{*}{$05(14.28)$} \\
\hline & & Research Scholars & - & \\
\hline \multirow[t]{2}{*}{02} & \multirow[t]{2}{*}{ Information access is very expensive } & Scientists & $08(22.85)$ & \multirow[t]{2}{*}{$11(31.42)$} \\
\hline & & Research Scholars & $03(08.57)$ & \\
\hline \multirow[t]{2}{*}{03} & \multirow[t]{2}{*}{ Information is scattered in too many sources } & Scientists & - & \multirow[t]{2}{*}{-} \\
\hline & & Research Scholars & - & \\
\hline \multirow[t]{2}{*}{04} & \multirow[t]{2}{*}{ Non Availability of E- Resource } & Scientists & - & \multirow[t]{2}{*}{-} \\
\hline & & Research Scholars & - & \\
\hline \multirow[t]{2}{*}{05} & \multirow[t]{2}{*}{ Marketing of Inf. Is not cost effective } & Scientists & - & \multirow[t]{2}{*}{-} \\
\hline & & Research Scholars & - & \\
\hline \multirow[t]{2}{*}{06} & \multirow[t]{2}{*}{ Language Barrier } & Scientists & $05(14.28)$ & \multirow[t]{2}{*}{$05(14.28)$} \\
\hline & & Research Scholars & - & \\
\hline \multirow[t]{2}{*}{07} & \multirow[t]{2}{*}{ Some other reasons i.e. location/hours/Environment/time } & Scientists & $12(34.28)$ & \multirow[t]{2}{*}{$14(40.0)$} \\
\hline & & Research Scholars & $02(5.71)$ & \\
\hline
\end{tabular}

Seven categories of reasons were identified and formulated to clarify common problem faced by respondents to access the information resources. The main problem as stated by $40 \%$ of the respondents is that they do not access the information resources like some other reasons i.e. location, hours, environment, time. In fact $31.42 \%$ CSSRI respondents state that they havefacedproblem to access the informationand is very expensive and then $14.28 \%$ lack of Information Technology, language barrier.

Table 16. Marketing Statement

\begin{tabular}{|c|c|c|c|c|c|c|c|}
\hline Sr. No & Marketing Statement & Users & $\begin{array}{c}\text { Strongly } \\
\text { Agree }\end{array}$ & Agree & $\begin{array}{l}\text { Not } \\
\text { Sure }\end{array}$ & Disagree & $\begin{array}{l}\text { Strongly } \\
\text { Disagree }\end{array}$ \\
\hline \multirow[t]{2}{*}{01} & \multirow{2}{*}{$\begin{array}{l}\text { Potential users are denied access to } \\
\text { Information Products/Services when fees } \\
\text { are charged in the library }\end{array}$} & $\mathbf{S}$ & $20(57.14)$ & $05(14.28)$ & - & - & $05(14.28)$ \\
\hline & & R.S & $04(11.42)$ & $01(2.85)$ & - & - & - \\
\hline \multirow[t]{2}{*}{02} & \multirow{2}{*}{$\begin{array}{l}\text { Users should pay fees for Information } \\
\text { Products/ Services }\end{array}$} & $\mathbf{S}$ & - & $20(57.14)$ & - & - & $05(14.28)$ \\
\hline & & R.S & - & $05(14.28)$ & - & - & - \\
\hline \multirow[t]{2}{*}{03} & \multirow[t]{2}{*}{ Fees are a major determent to library use } & $\mathbf{S}$ & - & $30(85.71)$ & - & - & - \\
\hline & & R.S & $02(5.71)$ & $03(08.57)$ & - & - & - \\
\hline \multirow[t]{2}{*}{04} & \multirow{2}{*}{$\begin{array}{l}\text { Developed Information Products/ Services } \\
\text { are very necessary so it is not a problem for } \\
\text { the users to pay for the developed } \\
\text { Information Products/Services }\end{array}$} & $\mathbf{S}$ & $30(85.71)$ & - & - & - & - \\
\hline & & R.S & $05(14.28)$ & - & - & - & - \\
\hline \multirow[t]{2}{*}{05} & \multirow{2}{*}{$\begin{array}{l}\text { Computerized literature search should be } \\
\text { part of the free normal library services }\end{array}$} & $\mathbf{S}$ & $05(14.28)$ & $25(71.42)$ & - & - & - \\
\hline & & R.S & $05(14.28)$ & - & - & - & - \\
\hline \multirow[t]{2}{*}{06} & \multirow{2}{*}{$\begin{array}{l}\text { Cost of the computerized literature search } \\
\text { should be paid by both the library and users. }\end{array}$} & $\mathbf{S}$ & - & $20(57.14)$ & $10(28.57)$ & - & - \\
\hline & & R.S & - & $05(14.28)$ & - & - & - \\
\hline \multirow[t]{2}{*}{07} & \multirow{2}{*}{$\begin{array}{l}\text { Cost of the computerized literature search } \\
\text { should be paid by the users only. }\end{array}$} & $\mathbf{S}$ & - & - & - & $20(57.14)$ & $10(28.57)$ \\
\hline & & R.S & - & - & - & $02(5.71)$ & $03(08.57)$ \\
\hline
\end{tabular}

\section{S= Scientists, R.S= Research Scholars}

To clarify the users' attitude towards marketing statements, seven categories of marketing statements were identified and formulated. In each category five variables were identified and formulated concerning strongly agree, agree, not sure, disagree, strongly disagree with the statement. Table No. 16 Indicate that $68.57 \%$ of the 
respondents were strongly agreed by potential users were denied access to information products and services when fees were charged in the library, $17.14 \%$ agree and $14.28 \%$ strongly disagree with the statement. $71.42 \%$ of the CSSRI respondents were agree reported the ability of the users should pay fees for information products and services, $14.28 \%$ strongly disagree. Most of the $94.28 \%$ users were agreed get the information from fees were a major determent to library use, only $5.71 \%$ strongly agree in the field of subject. Out of $100 \%$ scientists and research scholars were strongly agreed by developed information products and services were very necessary so it is not a problem for the users to pay for the developed information products and services with the statement. Only $28.57 \%$ respondents were strongly agreed with the statement of computerized literature search should be part of the free library services, $71.42 \%$ agree with it. In fact $62.85 \%$ respondents were disagreed with the statement by cost of the computerized literature search should be paid by the users only and then $37.14 \%$ strongly disagree. More than $71.42 \%$ scientists and research scholars were agreed by the cost of the computerized literature search should be paid by both the library and users and $28.57 \%$ not sure with the statement.

Table 17. Attitude towards Marketing

\begin{tabular}{|c|c|c|c|c|c|c|c|}
\hline Sr. No & Attitude Towards Marketing & Users & $\begin{array}{l}\text { Strongly } \\
\text { Agree }\end{array}$ & Agree & $\begin{array}{l}\text { Not } \\
\text { Sure }\end{array}$ & Disagree & $\begin{array}{l}\text { Strongly } \\
\text { Disagree }\end{array}$ \\
\hline \multirow[t]{2}{*}{01} & \multirow{2}{*}{$\begin{array}{l}\text { As a user I always look forward to new } \\
\text { Information Products \& Services }\end{array}$} & $\mathbf{S}$ & $30(85.71)$ & - & - & - & - \\
\hline & & R.S & 05 (14.28) & - & - & - & - \\
\hline \multirow[t]{2}{*}{02} & \multirow{2}{*}{$\begin{array}{l}\text { As a user I am ready to pay for developed } \\
\text { Information Product \& Service which is } \\
\text { Introduced. }\end{array}$} & $\mathbf{S}$ & $25(71.42)$ & 05 (14.28) & - & - & - \\
\hline & & R.S & - & 05 (14.28) & - & - & - \\
\hline \multirow[t]{2}{*}{03} & \multirow{2}{*}{$\begin{array}{l}\text { Potential users are denied access to Information } \\
\text { Products \& Services when fee charged in the } \\
\text { library }\end{array}$} & $\mathbf{S}$ & - & - & $25(71.42)$ & $05(14.28)$ & - \\
\hline & & R.S & - & - & $02(5.71)$ & 03 (08.57) & - \\
\hline \multirow[t]{2}{*}{04} & \multirow{2}{*}{$\begin{array}{l}\text { Information Products \& Services of the library } \\
\text { should be made available to outside users. }\end{array}$} & $\mathbf{S}$ & - & - & $28(80.0)$ & $02(5.71)$ & - \\
\hline & & R.S & & - & 05 (14.28) & - & - \\
\hline \multirow[t]{2}{*}{05} & \multirow[t]{2}{*}{ Outside users should be charged heavily. } & $\mathbf{S}$ & - & - & $20(57.14)$ & $10(28.57)$ & - \\
\hline & & R.S & - & - & $05(14.28)$ & - & - \\
\hline \multirow[t]{2}{*}{06} & \multirow{2}{*}{$\begin{array}{l}\text { Present pricing policy of Information Products } \\
\& \text { Services of your library is adequate. }\end{array}$} & $\mathbf{S}$ & $25(71.42)$ & $05(14.28)$ & - & - & - \\
\hline & & R.S & - & $05(14.28)$ & - & - & - \\
\hline \multirow[t]{2}{*}{07} & \multirow{2}{*}{$\begin{array}{l}\text { Users feedback is essential to assess the quality } \\
\text { and pricing of Information Products \& Services. }\end{array}$} & $\mathbf{S}$ & $30(85.71)$ & - & - & - & - \\
\hline & & R.S & $05(14.28)$ & - & - & - & - \\
\hline
\end{tabular}

\section{S= Scientists, R.S $=$ Research Scholars}

To clarify the users' attitude towards marketing statements, seven categories of marketing statements were identified and formulated. In each category five variables were identified and formulated concerning strongly agree, agree, not sure, disagree, strongly disagree with the statement. Table No. 17 Indicate that 100\% of the respondents were strongly agreed with both the statement 'As a user I always look forward to new information products \& services' and 'users feedback is essential to assess the quality and pricing of information products \& services' in the library. $71.42 \%$ of the CSSRI respondentswere strongly agree reported the ability 'As a user I am ready to pay for developed Information Product \& Service which is introduced and then only $28.57 \%$ agree. Majority of them $77.14 \%$ respondents were not sure to 'potential users were denied access to information products and services when fee charged in the library' and $22.85 \%$ disagree with the statement of attitude towards marketing. In fact $94.28 \%$ scientists and research scholars were not sure to 'Information Products \&Services of the library should be made available to outside users' and only $5.71 \%$ disagree. More than $71.42 \%$ respondents were strongly agreed regarding the statement such as 'present pricing policy of Information Products \& Services of your library is adequate' and only $28.57 \%$ agree.

Table 18. Level of Satisfaction

\begin{tabular}{|c|c|c|c|c|c|c|c|}
\hline Sr. No & Level of Satisfaction & Users & $\begin{array}{l}\text { Completely } \\
\text { Satisfied }\end{array}$ & $\begin{array}{c}\text { Very } \\
\text { Satisfied }\end{array}$ & $\begin{array}{l}\text { Moderately } \\
\text { Satisfied }\end{array}$ & $\begin{array}{l}\text { Very little } \\
\text { Satisfied }\end{array}$ & $\begin{array}{c}\text { Not at all } \\
\text { Satisfied }\end{array}$ \\
\hline \multirow[t]{2}{*}{01} & \multirow{2}{*}{$\begin{array}{l}\text { Collection of library materials (Books, Journals } \\
\text { etc) }\end{array}$} & $\mathbf{S}$ & $30(85.71)$ & - & - & - & - \\
\hline & & R.S & $05(14.28)$ & - & - & - & - \\
\hline \multirow[t]{2}{*}{02} & \multirow[t]{2}{*}{ Cleanliness of the library. } & $\mathbf{S}$ & $30(85.71)$ & - & - & - & - \\
\hline & & R.S & $05(14.28)$ & - & - & - & - \\
\hline \multirow[t]{2}{*}{03} & \multirow[t]{2}{*}{ Lighting and ventilation. } & $\mathbf{S}$ & $30(85.71)$ & - & - & - & - \\
\hline & & R.S & $05(14.28)$ & - & - & - & - \\
\hline \multirow[t]{2}{*}{04} & \multirow[t]{2}{*}{ Computer \& Networking facilities of the library } & $\mathbf{S}$ & - & $30(85.71)$ & - & - & - \\
\hline & & R.S & - & $05(14.28)$ & - & - & - \\
\hline 05 & Seating arrangement of the library. & $\mathbf{S}$ & - & $30(85.71)$ & - & - & - \\
\hline
\end{tabular}


Marketing of Information Products \& Services by the Research Scholars \& Scientists in Central Soil

\begin{tabular}{|c|l|c|c|c|c|c|c|}
\hline & & R.S & - & $05(14.28)$ & - & - & - \\
\hline 06 & Functional organization of the library. & S & - & $30(85.71)$ & - & - & - \\
\cline { 3 - 8 } & & R.S & - & $05(14.28)$ & - & - & - \\
\hline 07 & Electronic resources. & S & & $30(85.71)$ & - & - & - \\
\cline { 3 - 9 } & & R.S & - & $05(14.28)$ & - & - & - \\
\hline \multirow{2}{*}{08} & \multirow{2}{*}{ Marketing activities of the library. } & S & - & - & $30(85.71)$ & - & - \\
\cline { 3 - 9 } & & R.S & - & - & $05(14.28)$ & - & - \\
\hline
\end{tabular}

\section{S= Scientists, R.S= Research Scholars}

To clarify the users' level of satisfaction with the statements, eight categories of following were identified and formulated. In each category five variables were identified and formulated concerning completely satisfied, very satisfied, moderately satisfied, very little satisfied, and last not at all satisfied with the statement. Table No. 18 Indicate that $100 \%$ of the respondents were completely satisfied with the following statementsi.e. collection of library materials (Books, Journals etc.), cleanliness of the library, and also lighting \& ventilation in the library. In fact CSSRI $100 \%$ respondents were very satisfied with the following statements i.e. computer \& networking facilities, sittingarrangement, functional organization, and also E-Resources of the library. 100\% of the scientists and research scholars were moderately satisfied with the statement i.e. marketing activities of the library.

\section{Finding of the Survey}

* Marketing of Information Products \& Services use gender wise the CSSRI library, Karnal under the ICAR male respondents were $82.85 \%$ than female respondents were $17.14 \%$ in the field.

- Marketing of Information Products and Services status wise use the CSSRI library more popular Scientists than the Research Scholars. Out of total respondents $85.71 \%$ Scientists and $14.28 \%$ Research Scholars were used the library products and services.

* $14.28 \%$ respondents were using the off line library thrice in a Week, $5.71 \%$ daily and $28.57 \%$ occasionally. In fact $34.28 \%$ users were using the online library daily, $11.42 \%$ weekly and $5.71 \%$ Scientists thrice in a week use the online library.

* Agricultural Science users i.e. Scientists and Research Scholars were mostly spend time on the offline and online CSSRI library. Only $2.85 \%$ respondents spend less than 30 minutes to 1 hour and $22.85 \% 1$ to 2 hours regarding offline time in the library on a visit.

* In fact $25.71 \%$ users were using the on-line library by more than 4 hours, $22.85 \%$ Scientists and Research Scholars both were 3 to 4 hours and $20 \%$ respondents 2 to 3 hours time spend in the library.

* Central Soil Salinity Research Institute Scientists use only 5.71\% 1 to 2 hour's time spends by online library.

* CSSRI Respondents were 100\% using the library for the purpose of Research work \& Writing/Presenting paper, and update knowledge were the second purpose for which users use the library i.e. $71.42 \%$.

* The third purpose for using the library i.e. $34.28 \%$ users were teaching and $22.85 \%$ education regarding which is used by Scientists on CSSRI, Karnal. In agricultural science i.e. CSSRI only14.28\% respondents were positively using the library for entertainment only.

* $17.14 \%$ of respondents identified the main reason for not using the library regularly is that they get lack of time, $17.14 \%$ followed by to get information elsewhere or online $48.57 \%$.

* $37.14 \%$ respondents were using the Current Awareness Services and 14.28\% translation services about the subject of interest need.

* The study shows that CSSRI respondents were maximum whoused the information services which $85.71 \%$ literature search while $37.14 \%$ photocopying of periodical articles. It has been found that $62.85 \%$ respondents make always use of reference services for the information need required the subject of interest positively.

* More than $71.42 \%$ of the respondents want subject books and reprints. In fact $37.14 \%$ respondents want need of information products i.e. reference books and information bulletin.

* $100 \%$ of the respondents keep themselves aware of \& used through reprographic, reprints, internet, literature search, and $71.42 \%$ by bibliographic, enquiry services and also $100 \%$ respondents aware of but not used by indexing, abstracting, newspaper, translation, document scanning/printing, circulation of periodical contents, standards.

* In fact CSSRI $100 \%$ users were not aware of SDI (Selective Dissemination of Information), repacking \& condensation.

* Majority of the $100 \%$ respondents used free of cost all the CSSRI library products and services.

* $71.42 \%$ users have access the online database relating in their subject field and $28.57 \%$ never used it.

* $71.42 \%$ respondents reported that the CERA was used and $37.14 \%$ of the users were using the KrishiKosh database relating in their subject field of interest. 
* Majority of the respondents $65.71 \%$ were able to keep up their self with innovations in their field to a great extent, $28.57 \%$ respondents were to a very great extent and $5.71 \%$ to a considerable extent.

* The main problem as stated by $40 \%$ of the respondents is that they do not access the information resources like some other reasons i.e. location, hours, environment, time. In fact 31.42\% CSSRI respondent's state that they have faced problem to access the information is very expensive and then $14.28 \%$ lack of Information Technology, language barrier.

* Indicate that $68.57 \%$ of the respondents were strongly agreed with the statement by potential users were denied access to Information Products and Services when fees were charged in the library, $17.14 \%$ agree and $14.28 \%$ strongly disagree.

* $71.42 \%$ of the CSSRI respondents were agree reported the ability of the users should pay fees for information products and services, $14.28 \%$ strongly disagree.

* Most of the $94.28 \%$ users were agreed get the information from fees were a major determent to library use, only $5.71 \%$ strongly agree in the field of subject.

* Out of $100 \%$ scientists and research scholars were strongly agreed by developed information products and services were very necessary so it is not a problem for the users to pay for the developed information products and services with the statement.

* Only $28.57 \%$ respondents were strongly agreed with the statement of computerized literature search should be part of the free library services, $71.42 \%$ agree with it.

* In fact $62.85 \%$ respondents were disagreed with the statement by cost of the computerized literature search should be paid by the users only and then $37.14 \%$ strongly disagree.

* More than $71.42 \%$ scientists and research scholars were agreed by the cost of the computerized literature search should be paid by both the library and users and $28.57 \%$ not sure with the statement.

* Indicate that $100 \%$ of the respondents were strongly agreed with the both statement 'As a user I always look forward to new information products \& services' and 'users feedback is essential to assess the quality and pricing of information products \& services' in the library.

* $71.42 \%$ of the CSSRI respondents were strongly agree reported the ability 'As a user I am ready to pay for developed Information Product \& Service which is introduced and then only $28.57 \%$ agree.

* Majority of them $77.14 \%$ respondents were not sure to 'potential users were denied access to information products and services when fee charged in the library' and $22.85 \%$ disagree with the statement of attitude towards marketing.

* In fact $94.28 \%$ scientists and research scholars were not sure to 'Information Products \& Services of the library should be made available to outside users' and only $5.71 \%$ disagree.

* More than $71.42 \%$ respondents were strongly agreed regarding the statement such as 'present pricing policy of Information Products \& Services of your library is adequate' and only $28.57 \%$ agree.

* Indicate that $100 \%$ of the respondents were completely satisfied with the following statements i.e. collection of library materials (Books, Journals etc.), cleanliness of the library, and also lighting \& ventilation in the library.

* In fact CSSRI $100 \%$ respondents were very satisfied with the following statements i.e. computer \& networking facilities, seating arrangement, functional organization, and also E-Resources of the library.

* $100 \%$ of the scientists and research scholars were moderately satisfied with the statement i.e. marketing activities of the library.

Based on the findings, the following Suggestions are put forward to improve the Marketing of Information Products and Services in CSSRI Karnal Library.

* An intensive effort was required from the part of the top management of the library, and authorities of the concerned ICAR to overcome the identified weakness.

* To improve the library, personnel should be made aware of the concepts and principles of modern marketing. So provide better provision for the library staff to attend in-service and career advancement courses.

* CSSRI library should adopt some of the marketing and promotional strategies including publications, programmers of events, media and effective presentation of information products and services through the library website.

* The library should adopt an appropriate marketing approach for developing information services and products properly.

* There should be a proper feedback mechanism to monitor the effectiveness of the services and products. Regular surveys of the respondents should be conducted to know the continuity/discontinuity of the existing services/products and initiation of new services/products.

\section{Acknowledgements}

First and foremost, I would like to thank the almighty God the most beneficent and merciful, who blessed me for completing this work. It is not possible to record in words the inspirational guidance of my father Sh. Som Nath 
kapoor, Mother Shanti devi \& also Dr. Joginder Singh (Associate Prof.), Dept. of Library \& Information Science from Kurukshetra University Kurukshetra.

\section{References}

[1]. A. K. Martey. Marketing Products and Services of academic libraries in Ghana. Libri. 50(4), 2000, $261-268$.

[2]. Amritpal Kaur. Marketing of Information Services and Products in University Libraries of Punjab and Chandigarh. Electronic Journal of Academic and Special Librarianship. 8(3), 2007.

[3]. Amritpal Kaur, Sarita Rani. Marketing of information services and products in university libraries of Punjab and Chandigarh: A study. IASLIC Bulletin. 52(2), 2007, 83-103.

[4]. Anil Kumar. Marketing of Information Products and Services by the Research Scholars and Faculty members by the Kurukshetra University Library in the disciplines of Social Science: A study, IOSR Journal of Humanities and Social Science. 19(2), 2014, 1-19.

[5]. B. R. Mandal, A. K, Poddar and J. C, Choudhury. Marketing of INSDOC Services: A Report Libraries and Information Centres as Profit Making Institution: New Delhi. 1998, 88.

[6]. D. Rajayalakshmi, S.Waghmare. Need for marketing of information services and products in academic libraries with special reference to Nagpur University automated services. Library practices for effective management: ILA seminar papers. 47th All India Library Conference, 20-23 Dec., 2001, Warrangal. New Delhi: ILA, 2001, 379-95.

[7]. G. Renborg. Marketing library services: How it all began. In IFLA General Conference - 63rd Conference Programme and Proceedings, 31 Aug., 1997- 05 Sep., 1997.Retrieved 28 September, 2004 [Cited 10 February 2013]. Available from http://www.ifla.org/IV/ifla63/63reng.htm

[8]. G.D. Ekpenyong. Marketing and promotion of information services in the University of Ibdan Library. Information Development. 19(3), 2003, 197-202.

[9]. H.H. Spalding, Wang, Jian. The challenges and opportunities of marketing academic libraries in the USA: experience of US Academic Libraries with Global Application. Library management. 27(6-7), 2006, 494-504.

[10]. I. Shariful, I. Nazmul. Marketing of library and information products and services: A theoretical analysis. Business Information Review. 26(2), 2009, 123-132.

[11]. I. Torres. Marketing Information Services: A research study. Documentaliste. 39(6), 2002, 290-297.

[12]. J. M. Kavulya. Marketing of library services: A case study of selected university libraries in Kenya. Library Management 25(3), 2004, $118-126$.

[13]. L. T. Abdulsalami. Marketing Information Services in Polytechnics libraries in Nigeria. Journal of Education and practice. 4(6), 2013,10-18.

[14]. M.H. Ansari, A. Akhtar and M. A. M, Khan. Marketing of library \& information products and services in digital era. Fifty five ILA national conferences, on library and information science in the digital era, 21-24 January, 2010. Greater Noida: Indian Library Association, 2010.

[15]. M. J. Zachert, R. V, Williams. Marketing measures for information services 77(2), 1986, 61-70. [Cited 10 February 2013]. Available from http:// www.sla.org/content/shop/speclibs.cfm

[16]. Nerisa Kumar. Marketing of Electronic Information Resources: A case of the J. D Rockefeller Research Library, Edgerton University. Journal of Library and Information Science. 34(1), 2008. (cited 9 March 2013) Available from http://jlis.glis.ntnu.edu.tw/intro/eng/show.asp

[17]. N. M. Munshi. Marketing of Information products \& services in Bangladesh: Theories and praqtices. Library herald. 42(4), 2004, 324331.

[18]. P. Kotler, A. R, Andreasen. Strategic Marketing for Non-Profit Organization. Companion Encyclopedia of Marketing: London. 1995, 930.

[19]. R. Sharma, P. K, Chaudhary. Marketing value added management information to user community: A case study of AIMA Library. Electronic Information Environment and Library Services: A Contemporary Paradigm. 48th All India Library Conference, 22-23 Jan. 2003, Bangalore. Delhi: Indian Library Association. 10(1), 2003, 438-46.

[20]. Shakeed Ahmad Khan. Application of social media of library and information services: A case study from Pakistan. 9(1), 2012 , 25-31. (Cited 18 March 2013) Available from http://webology.org/2012/v9nl/a93.html

[21]. S. A. Brown, S. A. Marketing the corporate information centre for success, 1997, 74-79.

[22]. S. O. Popoola. Faculty awareness and use of library information products and service in Nigerian universities. Malaysian Journal of Library \& Information Science. 13(1), 2008, 91-102.

[23]. T. Levitt. The Marketing imagination, Macmillan: New York, 1986, 153.

[24]. Vij, Rajiv. Marketing of library products and services in India. International indexed \& referred research journal 3(34), 2012, 89-91.

\section{About Author}

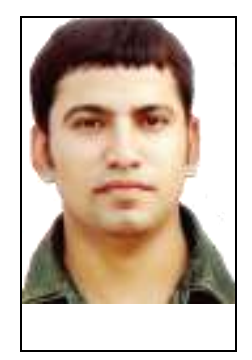

Anil kapoor is presently Librarian (H.O.D in Library) in the Swift group of Colleges Rajpura, Patiala. He holds a Ph.D (Pursuing) in Library \& Information Science from Kurukshetra University Kurukshetra. He published than 5 research paper in National \& International professional journals.

E-Mail: anilkapoorkapoor@ rediffmail.com,

E-Mail: $\underline{\text { dranilkapoor83@gmail.com }}$ 
Appendix - 1

Questionnaire for Users

PART-A: PERSONAL PROFILE (Please $(\checkmark)$ Mark in the appropriate boxes)

1. Name :Dr/Mr./Ms/Mrs

2. Name of Your Institute :

3. Gender : Male Female

4. Age Group (in years) $\quad: 18-25 \quad 26-35 \quad 36-45 \quad 46$ \& above

5. Status : Research Scholars Scientists

PART-B: LIBRARY USE PATTERN

1. How often do you use the library? (Please $\sqrt{ }$ only one option either offline otherwise online)

$\begin{array}{ll}\text { Off Line } & \text { Online } \\ \text { Daily } & \text { Daily } \\ \text { Weekly } & \text { Weekly } \\ \text { Thrice in a week } & \text { Thrice in a week } \\ \text { Occasionally } & \text { Occasionally } \\ \text { Never } & \text { Never }\end{array}$

2. Average time spent in the library on a visit? (Please $\sqrt{ }$ only one option either offline otherwise online)

$\begin{array}{ll}\text { Off Line } & \text { Online } \\ \text { Less than } 30 \text { Minutes to } 1 \text { Hour } & \text { Less than } 30 \text { Minutes to } 1 \text { Hour } \\ 1 \text { to } 2 \text { hours } & 1 \text { to } 2 \text { hours } \\ 2 \text { to } 3 \text { hours } & 2 \text { to } 3 \text { hours } \\ 3 \text { to } 4 \text { hours } & 3 \text { to } 4 \text { hours } \\ \text { More than } 4 \text { hours } & \text { More than } 4 \text { hours }\end{array}$

3. For what Purpose do you use the library? (You may $\sqrt{ }$ more than one option)

Teaching

Research Work

Entertainment

Updating Knowledge
Education

writing Paper \& Presenting Paper

Translation

Any Other (Pl. Specify

4. If you do not use the library regularly, what is the reason for not using the library regularly? (You may $\sqrt{ }$ more than one option)
Lack of time
Insufficient Material
Get information elsewhere or online
Lack of trained staff
Inconvenient working hours
Library staff is not helpful
Inconvenient location
Any Other (Pl. Specify

\section{PART-C: MARKETING OF INFORMATION PRODUCTS \& SERVICES}

1. Which are the Information Services that you need to find? (You may $\sqrt{ }$ more than one option)

Current Awareness Services

Newspaper clippings

Indexing/Abstracting Services

Translation Services

Literature Search

Photocopying of Periodical Articles
SDI

Circulation of Periodical Content

Reference Services

Inter Library Loan

Repackaging \& Condensation Service Any other (Pl. Specify)

2. Which are the Information Products that you need to find? (You may $\sqrt{ }$ more than one option)

Subject Books

Information Bulletin

Reprints

Online Products

Review

Index

Abstracts Lists
Reference Books

Standards/Patents

Thesis/Dissertation

Current Awareness Bulletins

Monographs

Bibliographic lists

Any other (Pl. Specify) 
3. The following is the list of Marketing of Information Products \& Services in the library. Are you aware of it? If yes, how frequently do you access and how much are you willing to pay for it?

\begin{tabular}{|c|c|c|c|c|c|c|c|c|c|c|}
\hline \multirow[b]{2}{*}{$\begin{array}{c}\text { Information Products \& } \\
\text { Services }\end{array}$} & \multicolumn{3}{|c|}{ Awareness } & \multicolumn{5}{|c|}{$\begin{array}{c}\text { Frequency to } \\
\text { Access }\end{array}$} & \multicolumn{2}{|c|}{$\begin{array}{c}\text { Willingness } \\
\text { to Pay }\end{array}$} \\
\hline & $\begin{array}{c}\text { Aware } \\
\text { of \& } \\
\text { used }\end{array}$ & $\begin{array}{c}\text { Aware } \\
\text { of but } \\
\text { not used }\end{array}$ & $\begin{array}{c}\text { Not } \\
\text { aware } \\
\text { of }\end{array}$ & 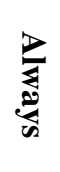 & 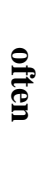 & 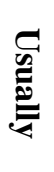 & 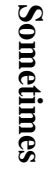 & Z & Free & Fee \\
\hline Indexing Service & & & & & & & & & & \\
\hline Abstracting Service & & & & & & & & & & \\
\hline Bibliographic Service & & & & & & & & & & \\
\hline $\begin{array}{l}\text { SDI (Selective Dissemination c } \\
\text { Information) }\end{array}$ & & & & & & & & & & \\
\hline Current Awareness Service & & & & & & & & & & \\
\hline Newspaper Clippings & & & & & & & & & & \\
\hline Consultancy Services & & & & & & & & & & \\
\hline Reprographic Service & & & & & & & & & & \\
\hline Reprints/Pre-Print Services & & & & & & & & & & \\
\hline Document Delivery Service & & & & & & & & & & \\
\hline Translation Service & & & & & & & & & & \\
\hline Inter Library Loan Service & & & & & & & & & & \\
\hline Internet Service & & & & & & & & & & \\
\hline Document Scanning/Printing & & & & & & & & & & \\
\hline Literature Searching & & & & & & & & & & \\
\hline Enquiry Services & & & & & & & & & & \\
\hline Repackaging \& Condensation & & & & & & & & & & \\
\hline Monographs & & & & & & & & & & \\
\hline Review & & & & & & & & & & \\
\hline Circulation of Periodical Contents & & & & & & & & & & \\
\hline Govt./Institute Publications & & & & & & & & & & \\
\hline Patents & & & & & & & & & & \\
\hline Standards & & & & & & & & & & \\
\hline CD ROM Database & & & & & & & & & & \\
\hline Online E-Resources & & & & & & & & & & \\
\hline
\end{tabular}

4. Are you familiar with online database relating in your subject field?

If yes, Please (Tick as many as applicable)

Yes/ No

NARD-National Agricultural Research Database

CERA-Consortium for E-Resources in Agriculture

NKRC- National Knowledge resources Consortium

AGRIS- Agricultural Information System

Krishi Kosh

5. How much you are able to keep up yourself with innovations in your field? (Please $\sqrt{ }$ only one option)
To a very great extent
To a great extent
To a considerable extent 
To a Moderate extent

To some extent

6. What are the common problems faced by you to access the Information Resources? (You may $\checkmark$ more than one option )

Lack of Information Technology

Information access is very expensive

Information is scattered in too many sources

Non availability of electronic resources

Marketing of Information is not cost effective

Language Barrier

Some other reasons i.e. location/hours/Environment/Time

7. Following are some statements regarding the operations of your library. Please read each and record your view by putting tick mark in the appropriate columns in the response scale.

\begin{tabular}{|c|c|c|c|c|c|c|}
\hline \multicolumn{2}{|r|}{ Marketing Statements } & \multirow{2}{*}{$\begin{array}{c}\text { Strongly } \\
\text { Agree }\end{array}$} & \multirow{2}{*}{ Agree } & \multirow{2}{*}{$\begin{array}{l}\text { Not } \\
\text { Sure }\end{array}$} & \multirow{2}{*}{ Disagree } & \multirow{2}{*}{$\begin{array}{l}\text { Strongly } \\
\text { Disagree }\end{array}$} \\
\hline 1. & $\begin{array}{l}\text { Potential users are denied access to Information } \\
\text { Products/Services when fees are charged in the library }\end{array}$ & & & & & \\
\hline 2. & Users should pay fees for Information Products/ Services & & & & & \\
\hline 3. & Fees are a major determent to library use & & & & & \\
\hline 4. & $\begin{array}{l}\text { Developed Information Products/Services are very } \\
\text { necessary so it is not a problem for the users to pay for the } \\
\text { developed Information Products \& Services }\end{array}$ & & & & & \\
\hline 5. & $\begin{array}{l}\text { Computerized literature search should be part of the free } \\
\text { normal library services }\end{array}$ & & & & & \\
\hline 6. & $\begin{array}{l}\text { Cost of the computerized literature search should be paid } \\
\text { by both the library and users. }\end{array}$ & & & & & \\
\hline 7. & $\begin{array}{l}\text { Cost of the computerized literature search should be paid } \\
\text { by the users only. }\end{array}$ & & & & & \\
\hline
\end{tabular}

8. Please indicate (Tick $\sqrt{ }$ mark) your Attitude towards Marketing with the library provisions to which you agreed with the following statement?

\begin{tabular}{|c|c|c|c|c|c|c|}
\hline \multicolumn{2}{|r|}{ Attitude towards Marketing } & \multirow{2}{*}{$\begin{array}{c}\text { Strongly } \\
\text { Agree }\end{array}$} & \multirow{2}{*}{ Agree } & \multirow{2}{*}{$\begin{array}{l}\text { Not } \\
\text { Sure }\end{array}$} & \multirow{2}{*}{ Disagree } & \multirow{2}{*}{$\begin{array}{l}\text { Strongly } \\
\text { Disagree }\end{array}$} \\
\hline 1. & $\begin{array}{l}\text { As a user I always look forward to new Information } \\
\text { Products \& Services }\end{array}$ & & & & & \\
\hline 2. & $\begin{array}{l}\text { As a user I am ready to pay for developed Information } \\
\text { Product \& Service which is introduced. }\end{array}$ & & & & & \\
\hline 3. & $\begin{array}{l}\text { Potential users are denied access to Information Products } \\
\& \text { Services when fee charged in the library. }\end{array}$ & & & & & \\
\hline 4. & $\begin{array}{l}\text { Information Products \& Services of the library should be } \\
\text { made available to outside users. }\end{array}$ & & & & & \\
\hline 5. & Outside users should be charged heavily. & & & & & \\
\hline 6. & $\begin{array}{l}\text { Present pricing policy of Information Products \& Services } \\
\text { of your library is adequate. }\end{array}$ & & & & & \\
\hline 7. & $\begin{array}{l}\text { Users feedback is essential to assess the quality and pricing } \\
\text { of Information Products \& Services. }\end{array}$ & & & & & \\
\hline
\end{tabular}

9. Please indicate (Tick $\sqrt{ }$ mark) your level of satisfaction with the library provisions to which you satisfied with the following statement?

\begin{tabular}{|c|l|c|c|c|c|c|}
\hline \multicolumn{2}{|c|}{ Level of Satisfaction } & $\begin{array}{c}\text { Completely } \\
\text { Satisfied }\end{array}$ & $\begin{array}{c}\text { Very } \\
\text { Satisfied }\end{array}$ & $\begin{array}{c}\text { Moderately } \\
\text { Satisfied }\end{array}$ & $\begin{array}{c}\text { Very little } \\
\text { Satisfied }\end{array}$ & $\begin{array}{c}\text { Not at all } \\
\text { Satisfied }\end{array}$ \\
\hline 1. & Collection of library materials (Books, Journals etc) & & & & & \\
\hline
\end{tabular}




\begin{tabular}{|c|l|l|l|l|l|l|}
\hline 2. & Cleanliness of the library. & & & & & \\
\hline 3. & Lighting and ventilation. & & & & & \\
\hline 4. & Computer \& Networking facilities of the library & & & & & \\
\hline 5. & Seating arrangement of the library. & & & & & \\
\hline 6. & Functional organization of the library. & & & & & \\
\hline 7. & Electronic resources. & & & & & \\
\hline 8. & Marketing activities of the library. & & & & & \\
\hline
\end{tabular}

10. Any other suggestion to improve library Products/Services.

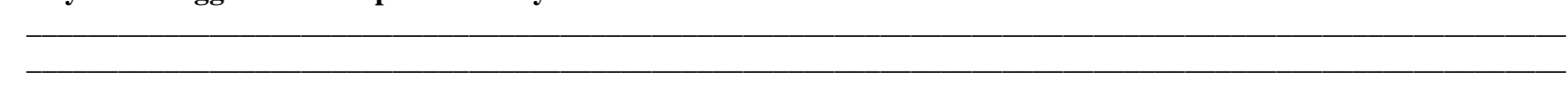

Thanks for your cooperation

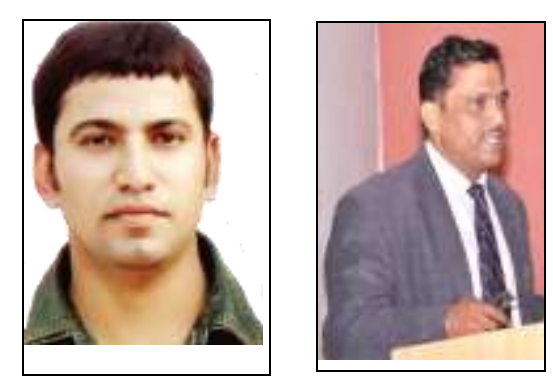

